\title{
Dry matter accumulation of winter wheat and barley at different sowing dates
}

\author{
Milan Mirosavljević ${ }^{1}$ Vojislava Momčilovići * Novo Pržulj² · \\ Ivana Maksimović ${ }^{\text {- Marina Putnik Delić3 }}$
}

${ }^{1}$ Institute of Field and Vegetable Crops, Maksima Gorkog 30, 21000 Novi Sad, Serbia

2University of Banja Luka, Faculty of Agriculture, Bulevar vojvode Petra Bojovića 1A, 78000 Banja Luka, Republika Srpska, Bosnia and Herzegovina ${ }^{3}$ University of Novi Sad, Faculty of Agriculture, Trg D. Obradovića 8, 21000 Novi Sad, Serbia

\begin{abstract}
Summary: Dry matter accumulation is one of the best estimates for crop reaction to the effect of genotype or environmental factors. However, there is a lack of information about comparative crop growth between wheat and barley under conditions of the Pannonian climate. The objectives of this work were to study and compare the patterns of biomass accumulation in wheat and barley, and identify the role of the logistic curve parameters in the determination of the final biomass. Therefore, field trials with two two-row winter barley and two winter whea cultivars were carried out in two successive growing seasons with four sowing dates. Results from our study showed that grain yield and crop biomass were under significant influence of cultivar and sowing date in both growing seasons. The highest grain yield and crop biomass at maturity were obtained with early sowing - first and second sowing date. There was a significant positive relationship between the crop biomass and grain yield in both species. Barley and wheat had similar strategies for biomass determination. Crop biomass at maturity was positively associated with the duration of growing phases, while the relationship with weighted mean absolute growth rate was negative. Early sowing enables prolongation in duration of different phases of crop biomass accumulation, leading to significant biomass and grain yield increase.

Keywords: barley, biomass, dry matter, grain yield, sowing, wheats
\end{abstract}

\section{Introduction}

In small grain cereals, yield is the product of the biomass accumulated during growing season and the proportion of dry matter allocated to the grains. Significant relationships between biomass at maturity and grain yield have been reported both in wheat (Agegnehu et al., 2014) and barley (de San Celedonio et al., 2014). Moreover, during grain filling period, a substantial part of grain dry matter can originate from different vegetative parts of the plants (Aynehband et al., 2011; Dodig et al., 2016). Therefore, biomass accumulated during pre- and post-anthesis period has an important role in the final grain yield determination (Koutroubas et al., 2012), especially under unfavourable environmental conditions (Madani et al., 2010; Savić et al., 2017; Dodig et al., 2017).

Corresponding author:

vojislava.momcilovic@ifvens.ns.ac.rs

Acknowledgment:

This study was funded by the Serbian Ministry of Education, Science and Technological Development within the project TR 31066.
Dry matter accumulation is a complex process, under a strong influence of the environment, cultivar and their interaction (Villegas et al., 2001). Different nonlinear and linear functions have been used to describe vegetative and reproductive growth for a number of cereal species (Ehdaie et al., 2008; Melchiori and Caviglia, 2008 and Maede et al., 2013), allowing a simple description of different plant processes (Thornley and France, 2007). The sigmoid nonlinear models, that produce s-shaped curve, are often applied to a wide range of agricultural processes (Archontoulis and Migue, 2015), such as plant height (Villegas et al., 2001), seedling emergence rate (Gan et al., 1996) and grain filling (Cossani et al., 2011). The accumulation of crop biomass also follows a typical sigmoid pattern (Danalatos et al., 2009). There are several different nonlinear sigmoid functions with biological meaning that could be used in modelling biomass accumulation. Logistic equation is one of the most widely used functions that was successfully applied to describe changes both in grain (Brdar et al., 2008) and crop dry matter (Jia et al., 2014). Furthermore, the Richards function has been applied to model growth of triticale plants (Villegas et al., 2001). In addition to Richards' model, 
Weibull function was a suitable equation for explaining triticale growth (Karadavut, 2009).

In the Pannonian region, wheat is the major winter cereal crop, followed by barley, triticale and oat. Optimal sowing period for wheat and barley cultivars is early and mid-October, while November sowing is considered late or undesirable, especially for barley (Mirosavljević et al., 2015). Biomass production is one of the best estimates for crop reaction to the effect of genotype or environmental factors, but there is a lack of information about comparative crop growth between wheat and barley under conditions of the Pannonian climate. Therefore, the objectives of the this study were to a) study and compare the patterns of biomass accumulation in wheat and barley, and b) identify role of the parameters of logistic curve in the determination of the final biomass under conditions of different growing seasons and sowing dates.

\section{Materials and Methods}

\section{Trial sites and treatments}

The field experiment was conducted during 2013/14 and 2014/15 growing seasons at the experimental field Rimski Šančevi of the Institute of Field and Vegetable Crops, Novi Sad, Serbia $\left(19^{\circ} 51 \mathrm{E}, 45^{\circ} 20 \mathrm{~N}\right.$, altitude 84 $\mathrm{m})$, on the non-carbonate chernozem soil. Treatments were a combination of two medium-early winter barley cultivars (Sonja and Sonate) and two medium-early winter wheat cultivars (Renesansa and Simonida) sown on four sowing dates in both seasons. Both species were sown on 27 September (SD1), 11 October (SD2), 25 October (SD3) and 8 November (SD4) in 2013/14, and 28 September (SD1), 11 October (SD2), 27 October (SD3) and 7 November (SD4) in 2014/15. Seeds were sown using a plot seeder at planting density of 350 viable seeds per $\mathrm{m}^{2}$ for winter barley and 450 viable seeds per $\mathrm{m}^{2}$ for winter wheat, a common practice in a large-scale production. The experiment was set up as a split-plot design with sowing dates as main plots and varieties as sub-plot treatments in three replications on plots of $10 \mathrm{~m}^{2}$. Each experimental plot was divided into two equal subplots, where one was used for destructive sampling and the other left intact for grain yield assessment. Standard cultivation practices were applied in each season. All trials were fertilized in doses consistent with good agricultural practice, based on an agrochemical analysis of the soil. Weeds were periodically removed by hand, while diseases and pests were prevented or controlled by spraying recommended fungicides and insecticides. No artificial irrigation was applied.

\section{Measurements}

Ten plants per replication were randomly sampled once or twice a week to study the dynamics of biomass accumulation, beginning 15 days after emergence until harvest maturity. Samples were dried at $80^{\circ} \mathrm{C}$ for $48 \mathrm{~h}$ before weighing. Samples were scaled-up to field units $t$ $\mathrm{ha}^{-1}$ using plant counts made at the beginning of stem elongation period (Zadoks' stage 30). Daily maximum $\left(\mathrm{T}_{\max }\right)$ and minimum $\left(\mathrm{T}_{\min }\right)$ air temperatures were obtained from a meteorological station located at the experimental field. Daily mean air temperature was calculated as $\mathrm{T}=0.5 \times\left(\mathrm{T}_{\max }+\mathrm{T}_{\min }\right)$ using a base temperature of $0{ }^{\circ} \mathrm{C}\left({ }^{\circ} \mathrm{C} \mathrm{d}\right)$.

\section{Data analysis}

Crop biomass data were fitted to the logistic curve (Verhulst, 1838):

$$
y=y_{\text {asym }} /\left(1+e^{-k^{\left(t-t_{\text {inf }}\right)}}\right)
$$

where $\mathrm{y}$ is the estimated crop biomass, $\mathrm{y}_{\text {asym }}$ is the asymptotic $\mathrm{Y}$ value, $\mathrm{t}$ is the time from emergence calculated in growing degree days, $t_{\text {inf }}$ is the inflection point at which growth is maximized, $\mathrm{k}$ controls the steepness of the curve. Crop biomass at maturity (BM) was considered to be complete when the yasym values reached $95 \%$ of the asymptote (Darroch and Baker, 1990). Also, $t_{\max }$ was considered to be the thermal time required to reach 0.95 yasym. Weighted mean absolute growth rate (WMAGR) is defined as the mean growth rate over the period when the crop accumulated most of the biomass. The duration of exponential growth (DUR) is defined as the period over which the crop accumulated most of the total biomass.

The WMAGR and DUR were calculated according to Pagelow Jr. et al. (1977) and Munakamwe et al. (2014):

$$
\mathrm{WMAGR}=\frac{k \times y_{\text {asym }}}{6} ; D U R=\frac{6}{k} .
$$

Data were subjected to a combined analysis of variance, treating the sowing date as the main plot and the species as the sub-plot. The cultivars were nested within species. Means were compared using the Tukey test $(\mathrm{P}<0.05)$. Correlation analysis was used to test traits correlation in both species. Moreover, trait association was analysed by linear regression analysis. Analysis of variance (ANOVA), nonlinear and linear regression and correlation analysis were performed using R 3.0.2 (R Development Core Team).

\section{Meteorological conditions}

Weather data were collected from the meteorological station located within the experimental field (Figure 1). The amount and distribution of precipitation and average daily temperature varied notably across the growing seasons. Weather conditions in 2013/14 were characterized by high level of precipitation and favorable temperatures in autumn. From December to March precipitation was extremely low leading to the appearance of mild drought, and influencing crop growth in early spring. From March until the end of growing season, weather conditions were characterized by high level of precipitation and 


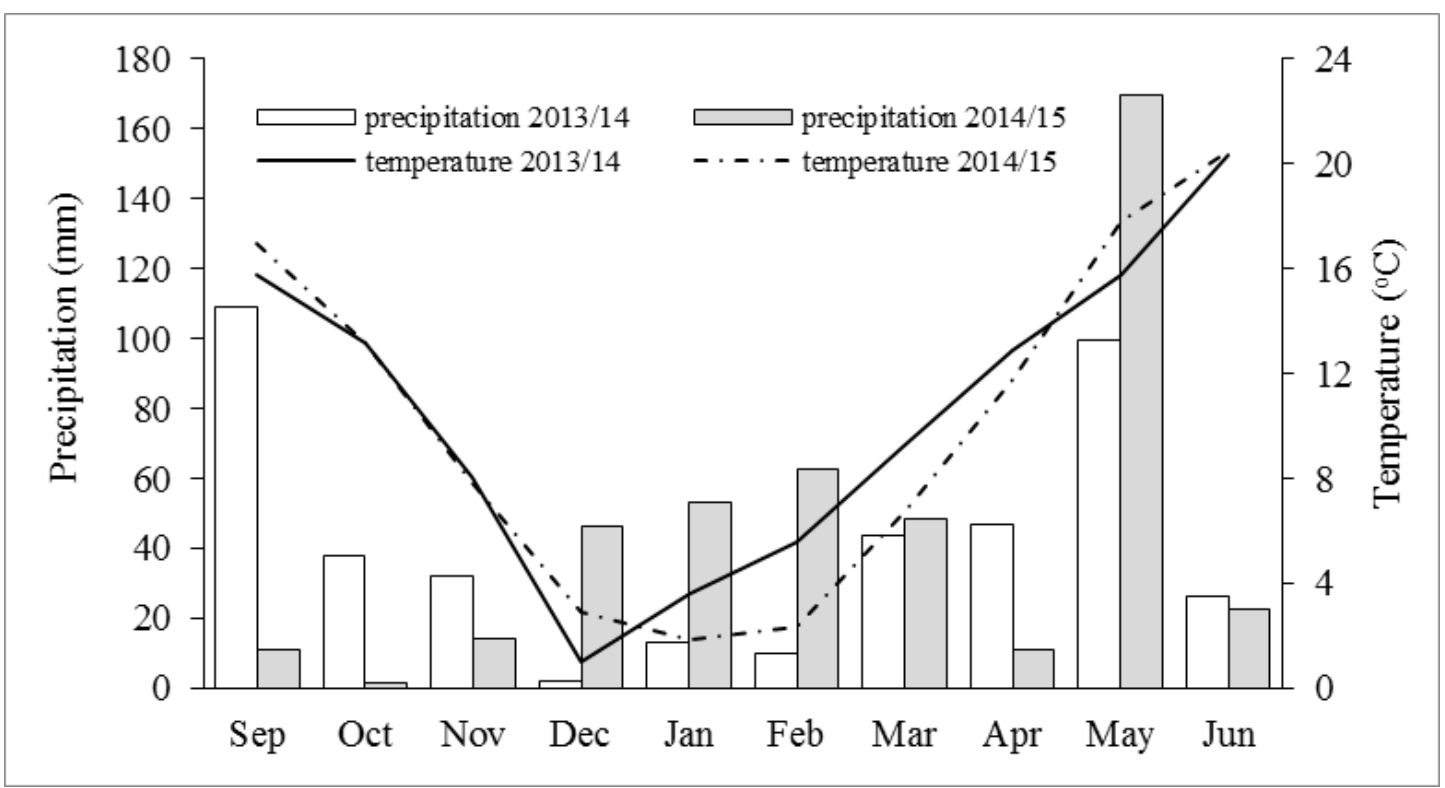

Figure 1. Monthly average air temperature and precipitation sum for the growing seasons 2013/14 and 2014/15

average temperature, enabling high biomass accumulation. The season 2014/15 saw lower temperature in spring and higher level of precipitation in winter and grain filling period than 2013/14. Furthermore, precipitation was more equally distributed in $2014 / 15$ than in the preceding year.

\section{Results and Discussion}

The crop biomass accumulation, calculated by fitting the data of crop dry weight into the logistic model, is shown in Table 2 and Figure 2. Since the values of $\mathrm{R}^{2}$ coefficient for the fitted logistic curve were higher than 0.97 , crop biomass accumulation was appropriately described by the logistic equation. Moreover, polynomial models have been used in wheat to describe biomass accumulation during the pre-anthesis (Pržulj and Momčilović, 2011a) and post-anthesis period (Pržulj and Momčilović, 2011b). However, these equations are without biological meanings and difficult to interpret (Peek et al., 2002). Therefore, non-linear sigmoid equations, such as logistic curve, are more useful to describe and analyse the crop growth process (Maede et al., 2013 and Archontoulis and Miguez, 2015).

Results from our study showed that grain yield was under significant influence of cultivar and sowing date in both growing seasons. Over all sources of variation, grain yield varied between $6.3 \mathrm{t} \mathrm{ha}^{-1}$ and $10.3 \mathrm{t} \mathrm{ha}^{-1}$ in winter barley and between $6.6 \mathrm{tha}^{-1}$ and $11.9 \mathrm{t} \mathrm{ha}^{-1}$ in winter wheat. Additionally, grain yield in both species was higher in 2014/15 than in 2013/14. Under conditions of mild temperatures and higher level of precipitation during the winter and grain filling period in 2014/15 growing season, plants had more vigorous growth in spring leading to higher biomass accumulation and grain yield than in 2013/14. As previously reported by Pržulj et al. (2015) and Dimitrijević et al. (2010), under conditions of the Pannonian plain growing season had significant influence on barley and wheat grain yield and other agronomic traits. Also, the difference between growing seasons, mainly in precipitation level and temperature conditions, during the pre-anthesis and post-anthesis period, led to significant variation in two main grain yield components - grain weight and grain number (Mirosavljević et al., 2017).

Winter wheat showed higher grain yield than barley in all cases, with the exception of SD2 in 2013/14 and SD4 in 2014/15. In the growing season 2013/14, grain yield variability across sowing dates ranged from $6.6 \mathrm{t} \mathrm{ha}^{-1}$ (SD4) to $8.3 \mathrm{t} \mathrm{ha}^{-1}$ (SD1) in barley, and from $6.7 \mathrm{t} \mathrm{ha}^{-1}$ (SD4) to $8.7 \mathrm{t} \mathrm{ha}^{-1}$ (SD1) in wheat. Further, in the following growing season grain yield declined by delaying the sowing date from $10.2 \mathrm{t} \mathrm{ha}^{-1}$ (SD4) to $8.7 \mathrm{t} \mathrm{ha}^{-1}$ (SD1) in barley and from $11.5 \mathrm{t} \mathrm{ha}^{-1}$ (SD4) to $8.4 \mathrm{t} \mathrm{ha}^{-1}$ (SD1) in wheat. These results indicated the importance of early sowing in the production of wheat and barley under climate conditions of the Pannonian plain. Mirosavljević et al. (2015) reported that optimization of sowing date led to a significant increase in crop biomass and grain yield. Due to early sowing, plants develop higher number of productive tillers and grains per secondary spike influencing final grain yield (Kiss et al., 2014). On the other hand, delayed sowing causes significant decrease in grain weight and consequently reduced final grain yield as a result of higher temperature during the grain filling period (White et al., 2011) and shortening of the grain filling period (Ferrise et al., 2010). 


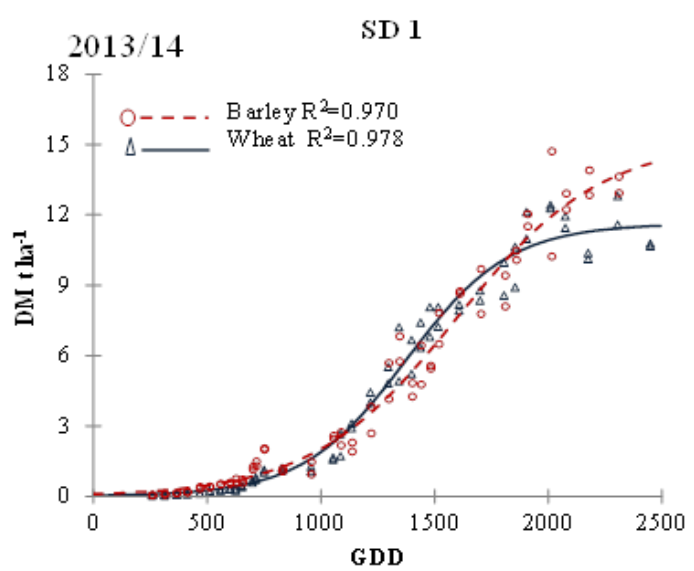

SD 2

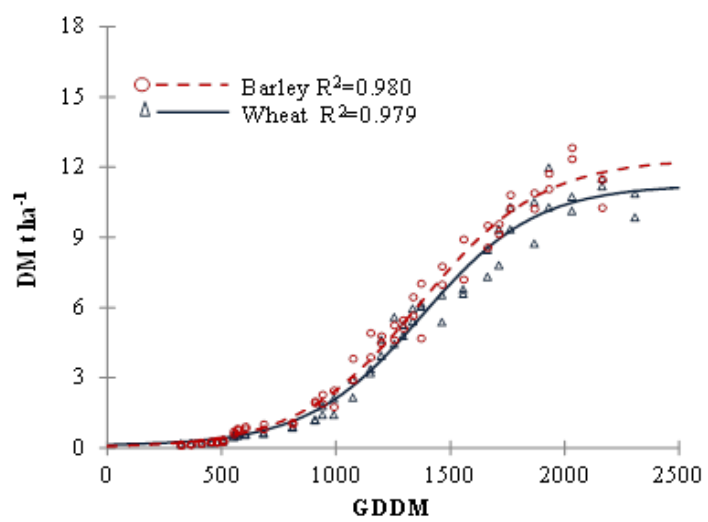

SD 3



SD 4

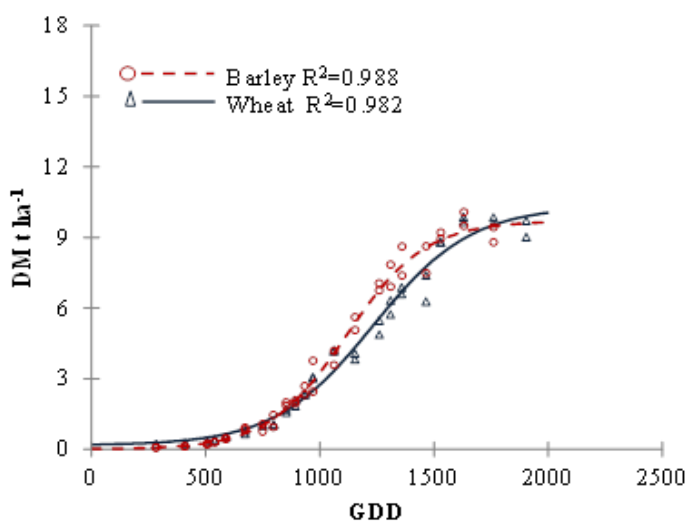

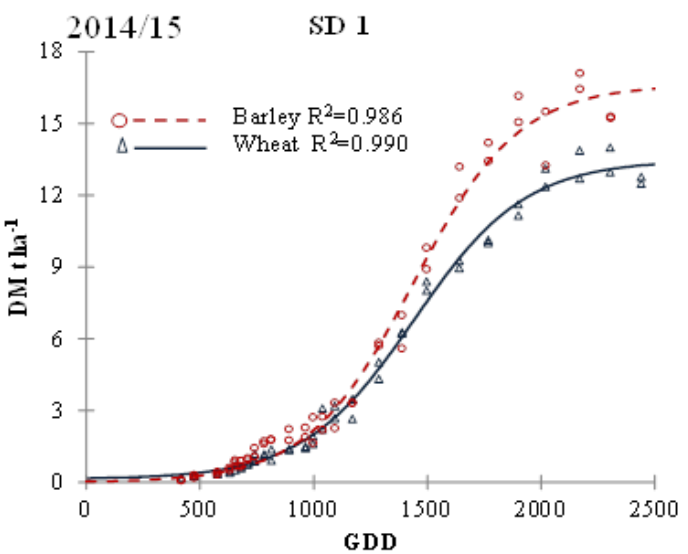

SD 2

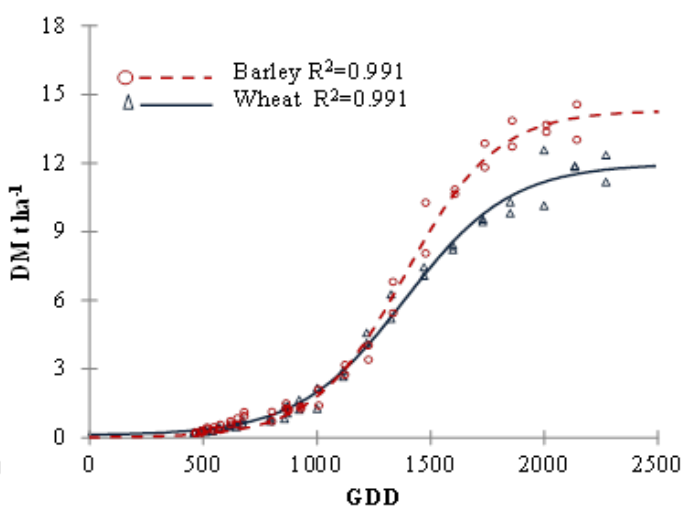

SD 3

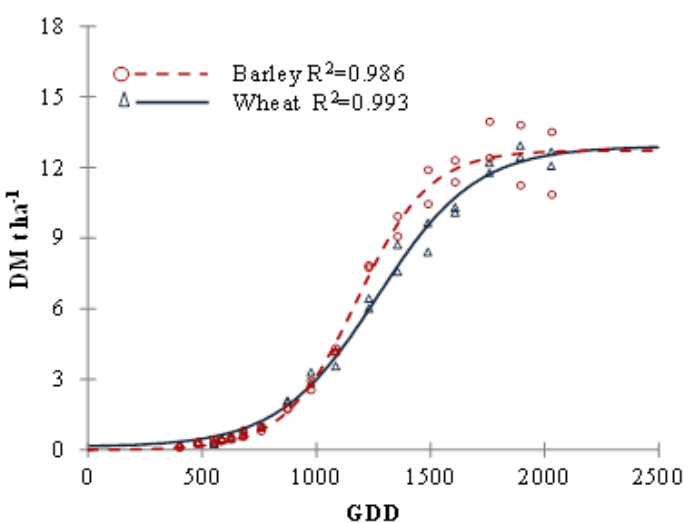

SD 2

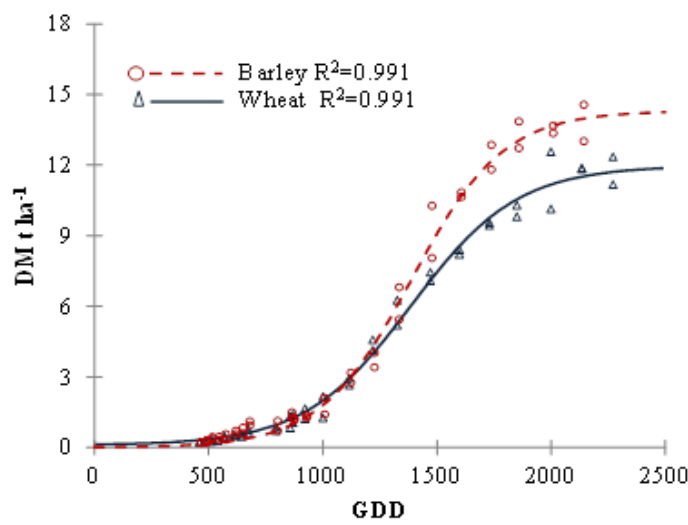

Figure 2. Patterns of biomass accumulation averaged over wheat and barley cultivars for four sowing dates in 2013/14 and 2014/15 
Table 1. Grain yield and aboveground biomass of barley (Sonja and Sonate) and wheat (Renesansa and Simonida) under four sowing dates in two growing seasons

\begin{tabular}{|c|c|c|c|c|c|c|c|c|c|c|}
\hline \multirow{2}{*}{$\begin{array}{l}\text { Growing } \\
\text { season }\end{array}$} & \multirow{2}{*}{ Species } & \multirow{2}{*}{ Cultivar } & \multicolumn{4}{|c|}{ Grain yield $\left(\mathrm{t} \mathrm{ha}^{-1}\right)$} & \multicolumn{4}{|c|}{ Biomass (t ha-1) } \\
\hline & & & SD1 & $\mathrm{SD} 2$ & SD3 & SD4 & $\mathrm{I}$ & II & III & IV \\
\hline \multirow[t]{6}{*}{$2013 / 14$} & Barley & Sonja & $8.3^{\mathrm{abcd}}$ & $8.2^{\mathrm{abcd}}$ & $6.3 \mathrm{~g}$ & $6.6^{\mathrm{fg}}$ & $13.6^{\mathrm{b}}$ & 12.0 cde & $10.3^{\mathrm{h}}$ & $9.4^{\mathrm{i}}$ \\
\hline & & Sonate & $8.4^{\mathrm{ab}}$ & $8.3^{\mathrm{abcd}}$ & $6.9^{\mathrm{efg}}$ & $6.7^{\mathrm{efg}}$ & $15.2^{\mathrm{a}}$ & $12.6^{c}$ & $11.7 \mathrm{def}$ & $10.2^{\mathrm{h}}$ \\
\hline & Wheat & Renesansa & $8.3^{\mathrm{abc}}$ & $7.3 \mathrm{def}$ & $6.9 \mathrm{efg}$ & $6.8^{\mathrm{efg}}$ & $12.4 \mathrm{~cd}$ & $11.1 \mathrm{fg}$ & $11.6^{\mathrm{ef}}$ & $10.2^{\mathrm{hi}}$ \\
\hline & & Simonida & $9.0^{\mathrm{a}}$ & $7.4 \mathrm{cdef}$ & $7.6^{\text {bcde }}$ & $6.6^{\mathrm{fg}}$ & $11.4^{\mathrm{ef}}$ & $11.4^{\mathrm{ef}}$ & $11.5^{\mathrm{ef}}$ & $10.5^{\mathrm{gh}}$ \\
\hline & & Barley mean & $8.3^{a}$ & $8.2^{a}$ & $6.6^{d}$ & $6.6^{d}$ & $14.4^{a}$ & $12.3^{b}$ & $11.0^{d e}$ & $9.8 f$ \\
\hline & & Wheat mean & $8.7^{a}$ & $7.4^{b}$ & $7.3 b c$ & $6.7^{c d}$ & $11.9^{b c}$ & $11.3^{c d}$ & $11 . c d 5$ & $10.3^{e f}$ \\
\hline \multirow[t]{6}{*}{$2014 / 15$} & Barley & Sonja & $10.3 \mathrm{bcd}$ & $9.1^{\mathrm{fgh}}$ & $9.0 \mathrm{ghi}$ & $7.8 j$ & $16.1^{b}$ & $14.0 \mathrm{~cd}$ & $11.6 \mathrm{fg}$ & $12.2^{\mathrm{ef}}$ \\
\hline & & Sonate & $10.1^{\mathrm{cde}}$ & $9.4^{\mathrm{efg}}$ & $9.1^{\mathrm{fgh}}$ & $9.6^{\text {defg }}$ & $17.2^{\mathrm{a}}$ & $14.6^{c}$ & $13.6^{\mathrm{d}}$ & $11.8^{\mathrm{efg}}$ \\
\hline & Wheat & Renesansa & $11.0^{\mathrm{b}}$ & $10.6^{\mathrm{bc}}$ & $9.2^{\mathrm{fgh}}$ & $8.2^{\mathrm{ij}}$ & $13.5^{\mathrm{d}}$ & $13.5^{\mathrm{d}}$ & $11.3 \mathrm{gh}$ & $10.4^{\mathrm{i}}$ \\
\hline & & Simonida & $11.9^{a}$ & $9.8^{\mathrm{def}}$ & $10.1^{\mathrm{cde}}$ & $8.5^{\text {hij }}$ & $14.4^{c}$ & $12.5^{\mathrm{e}}$ & $12.5^{\mathrm{e}}$ & $10.6^{\mathrm{hi}}$ \\
\hline & & Barley mean & $10.2^{b}$ & $9.2^{c d}$ & 9.0 cde & $8.7 d e$ & $16.7 a$ & $14.3^{b}$ & $12.6^{d e}$ & 12.0de \\
\hline & & Wheat mean & $11.5^{a}$ & $11.2^{b}$ & $9.6^{b c}$ & $8.4^{e}$ & $14.0^{b c}$ & $13.0^{c d}$ & $11.9^{e}$ & $10.5 f$ \\
\hline
\end{tabular}

$*$ Different letters represent significant difference between cultivars $(\mathrm{p}<0.05)$

A significant variation in crop biomass at maturity was recorded across the studied cultivars and sowing dates (Table 1). The biomass ranged from $9.4 \mathrm{t} \mathrm{ha}^{-1}$ to $17.2 \mathrm{t} \mathrm{ha}^{-1}$ and from $10.2 \mathrm{ha}^{-1}$ to $14.4 \mathrm{t} \mathrm{ha}^{-1}$ in winter barley and wheat, respectively. When all studied environments were considered, barley tended to have higher biomass than wheat under the conditions of early sowing (SD1 and SD4). The highest biomass in barley was obtained by sowing in SD1, and by delaying the sowing date barley biomass decreased almost linearly from $14.4 \mathrm{t} \mathrm{ha}^{-1}$ in SD1 to $9.8 \mathrm{t} \mathrm{ha}^{-1}$ in SD4 and from $16.7 \mathrm{t} \mathrm{ha}^{-1}$ in SD1 to $9.8 \mathrm{t} \mathrm{ha}^{-1}$ in SD4 in 2013/14 and $2014 / 15$, respectively. In wheat, influence of sowing date was less pronounced, and in 2013/14 there was no significant difference between the first three sowing dates and in the following season between the first two sowing dates. As a result of late sowing, duration of phenological development significantly decreased (Kiss et al., 2014) causing shortage of photosynthetic assimilates for translocation in the developing grain (Ferrise et al., 2010).

Overall, there was a significant positive relationship between the crop biomass and grain yield in both species (Figure 3), though this relationship was higher in wheat $(r=0.84)$ than in barley $(r=0.79)$. Also, changes in crop biomass at maturity are closely related to differences in grain number per unit area (Garcia et al., 2013; Prado et al., 2017). Moreover, increase in grain yield in $20^{\text {th }}$ century was mainly the result of changes in assimilate partitioning to the spike and increase of grain number per unit area, and modern cultivars had already achieved high values of harvest index. Therefore, further grain yield improvement should be achieved by increasing crop biomass and maintaining high values of harvest index (Zhou et al., 2014).

Generally, significant difference between species for thermal time needed to reach maximum biomass value $\left(t_{\max }\right)$ were observed only in the second growing season, while in the first growing season the difference was not significant. Further, duration of $t_{\max }$ varied significantly between sowing dates in both growing seasons. In barley, duration of $t_{\max }$ was significantly higher in SD1 than in SD3 and SD4 in both growing seasons. In wheat, there was no difference in duration of this period between SD1 and SD2 in both growing seasons. Duration of period to maximum growth rate ( $\mathrm{i}_{\text {inf }}$ ) varied from $1229^{\circ} \mathrm{C} \mathrm{d}^{-1}$ to $1431^{\circ} \mathrm{C} \mathrm{d}^{-1}$, showing no significant difference between wheat and barley in both growing seasons. Duration of $t_{\text {inf }}$ was lower in late sowing dates (SD3 and SD4), although these differences were mainly not significant.

On average, winter barley cultivars had lower weighted mean absolute growth rate (WMAGR) than wheat in 2013/14 growing season, while in the following season barley had higher values of WMAGR. By delaying the sowing date, WMAGR increased almost linearly both in wheat and barley. The duration of exponential growth (DUR) in 2013/14 was slightly longer in barley than in wheat, while in the following growing season wheat had higher values of DUR. By delaying the sowing date, duration of exponential growth phase decreased in 2013/14 in barley from $1284{ }^{\circ} \mathrm{C} \mathrm{d}^{-1}$ in SD1 to $685^{\circ} \mathrm{C} \mathrm{d}^{-1}$ in SD4 and in wheat from $1022{ }^{\circ} \mathrm{C} \mathrm{d}^{-1}$ in SD1 to $841{ }^{\circ} \mathrm{C} \mathrm{d}^{-1}$ in SD4. A similar reduction trend was recorded in the following growing season, where the duration of DUR declined 


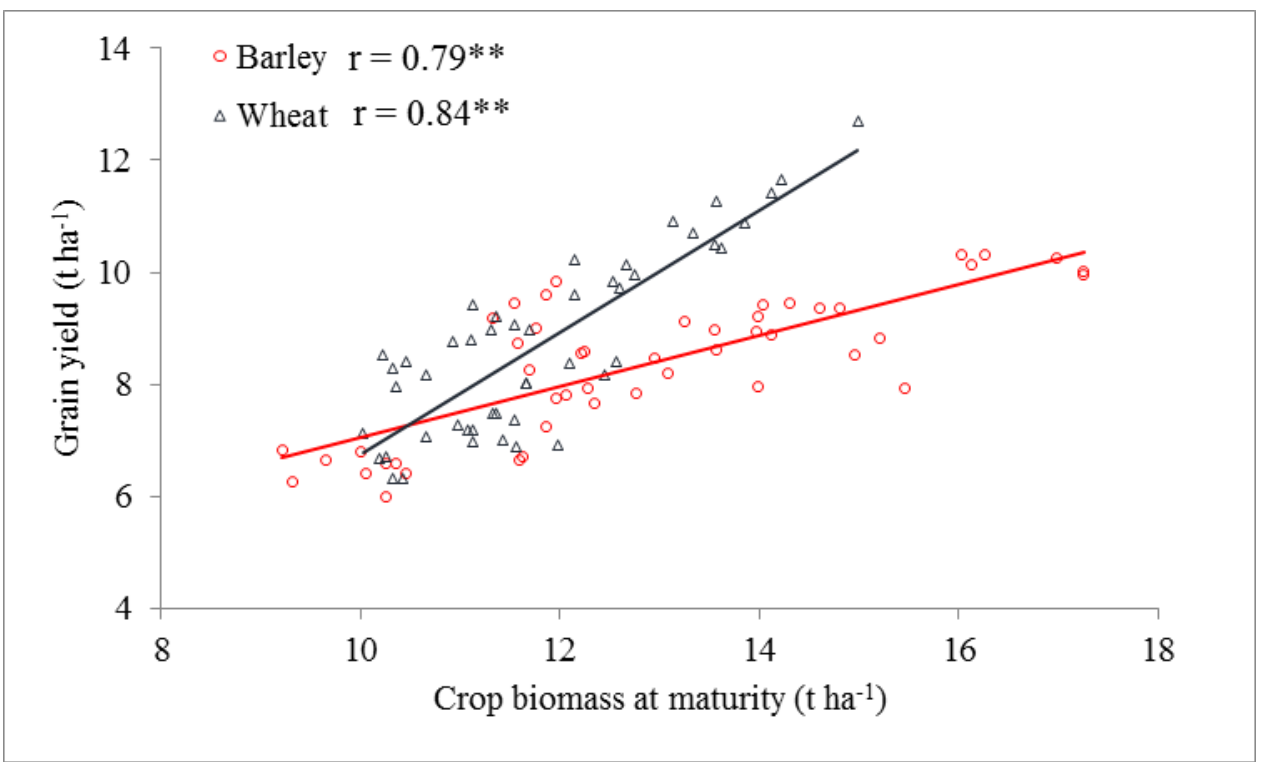

Figure 3. Relationship between grain yield (YIL) and crop biomass at maturity in winter barley (open circle) and wheat (open triangles)

Table 2. Thermal time needed to reach maximum biomass value $\left(t_{\max }\right)$, duration of period to maximum growth rate ( $\left.\mathrm{t}_{\mathrm{inf}}\right)$, weighted mean absolute growth rate (WMAGR), duration of exponential growth (DUR) in barley and wheat under four sowing dates in 2013/14 and 2014/15

\begin{tabular}{|c|c|c|c|c|c|c|c|c|c|}
\hline \multirow[b]{2}{*}{ Species } & \multirow[b]{2}{*}{$\begin{array}{c}\text { Sowing } \\
\text { date }\end{array}$} & \multicolumn{3}{|c|}{$2013 / 14$} & \multirow[b]{2}{*}{$\begin{array}{l}\text { DUR } \\
\left({ }^{\circ} \mathrm{C} \mathrm{d}^{-1}\right)\end{array}$} & \multicolumn{4}{|c|}{$2014 / 15$} \\
\hline & & $\begin{array}{l}\mathrm{t}_{\max } \\
\left({ }^{\circ} \mathrm{C} \mathrm{d}^{-1}\right)\end{array}$ & $\begin{array}{l}\mathrm{t}_{\text {inf }} \\
\left({ }^{\circ} \mathrm{C} \mathrm{d}^{-1}\right)\end{array}$ & $\begin{array}{l}\text { WMAGR } \\
\left(\mathrm{kg} \mathrm{ha}^{-1}{ }^{\circ} \mathrm{C}\right. \\
\left.\mathrm{d}^{-1}\right) \\
\end{array}$ & & $\begin{array}{l}\mathrm{t}_{\max } \\
\left({ }^{\circ} \mathrm{C} \mathrm{d}^{-1}\right)\end{array}$ & $\begin{array}{l}\mathrm{t}_{\text {inf }} \\
\left({ }^{\circ} \mathrm{C} \mathrm{d}^{-1}\right)\end{array}$ & $\begin{array}{l}\text { WMAGR } \\
\left(\mathrm{kg} \mathrm{ha}^{-1}{ }^{\circ} \mathrm{C}\right. \\
\left.\mathrm{d}^{-1}\right) \\
\end{array}$ & $\begin{array}{l}\text { DUR } \\
\left({ }^{\circ} \mathrm{C} \mathrm{d}^{-1}\right)\end{array}$ \\
\hline \multirow[t]{4}{*}{ Barley } & SD1 & $2420^{a}$ & $1373^{a}$ & $3.98^{\mathrm{f}}$ & $1264^{a}$ & $2117^{\mathrm{ab}}$ & $1317^{\mathrm{ab}}$ & $6.71^{\text {cde }}$ & $926^{\mathrm{abc}}$ \\
\hline & SD2 & $2154^{\mathrm{abc}}$ & $1277^{a}$ & $4.80^{\mathrm{ef}}$ & $1068^{b}$ & $1852^{\text {cde }}$ & $1373^{\mathrm{ab}}$ & $7.94 \mathrm{bc}$ & $773^{d}$ \\
\hline & SD3 & $1995 \mathrm{bcd}$ & $1241^{a}$ & $5.70 \mathrm{de}$ & $941 \mathrm{bc}$ & $1642^{\mathrm{e}}$ & $1233^{b}$ & $8.53^{\mathrm{b}}$ & $785^{d}$ \\
\hline & SD4 & $1619^{\mathrm{e}}$ & $1240^{a}$ & $9.53^{a}$ & $685^{\mathrm{d}}$ & $1798^{\mathrm{de}}$ & $1234^{b}$ & $11.50^{\mathrm{a}}$ & $631^{\mathrm{e}}$ \\
\hline \multirow[t]{4}{*}{ Wheat } & SD1 & $2212^{\mathrm{ab}}$ & $1399 a$ & $5.50 \mathrm{de}$ & $1022^{b}$ & $2163^{a}$ & $1431^{a}$ & $6.00^{\mathrm{e}}$ & $990^{a}$ \\
\hline & SD2 & $2094^{\mathrm{bc}}$ & $1371^{a}$ & $6.05^{\mathrm{cd}}$ & $973^{\mathrm{bc}}$ & $2082^{\mathrm{abc}}$ & $1395^{\mathrm{ab}}$ & $6.60 \mathrm{de}$ & $934^{\mathrm{ab}}$ \\
\hline & SD3 & $1884^{\text {cde }}$ & $1323^{a}$ & $6,89 \mathrm{bc}$ & $901 \mathrm{bc}$ & $1904 \mathrm{bcd}$ & $1229 \mathrm{~b}$ & $6.75^{\text {cde }}$ & $867 \mathrm{bcd}$ \\
\hline & SD4 & $1780^{\mathrm{de}}$ & $1279^{a}$ & $7.74^{\mathrm{b}}$ & $841^{\mathrm{cd}}$ & $1854^{\text {cde }}$ & $1268^{\mathrm{ab}}$ & $7.86 \mathrm{~b}^{\mathrm{cd}}$ & $859 \mathrm{~cd}$ \\
\hline Barley mean & & $2047^{a}$ & $1283^{a}$ & $5.00^{\mathrm{b}}$ & $990^{a}$ & $1852^{\mathrm{b}}$ & $1289^{a}$ & $8.67^{a}$ & $779^{b}$ \\
\hline Wheat mean & & $1992^{a}$ & $1343^{a}$ & $6.55^{a}$ & $934 \mathrm{~b}$ & $2001^{a}$ & $1331^{a}$ & $6.80^{\mathrm{b}}$ & $907 a$ \\
\hline
\end{tabular}

*Different letters represent significant difference between cultivars $(\mathrm{p}<0.05)$

in barley from $926{ }^{\circ} \mathrm{C} \mathrm{d}^{-1}$ in SD1 to $631{ }^{\circ} \mathrm{C} \mathrm{d} \mathrm{d}^{-1}$ in SD4 and in wheat from $990{ }^{\circ} \mathrm{C} \mathrm{d}^{-1}$ in SD1 to $859{ }^{\circ} \mathrm{C} \mathrm{d}^{-1}$ in SD4. Variation in weather conditions between the growing seasons led to a difference in duration of growing phases.

Figure 4 illustrates the relationships between the crop biomass and biological parameters of logistic curve in wheat and barley in two growing seasons. Equal pattern of relationship between crop biomass and the studied parameters has been reported for both species, indicating that barley and wheat had similar strategies for biomass determination. Analysis of the biomass accumulation pattern showed that biomass at maturity (BM) was positively related to duration of different growing phases (thermal time needed to reach maximum biomass value $-t_{\max }$, duration of period to maximum growth rate $-t_{\text {inf }}$ and duration of exponential growth - DUR). However, different levels of correlation between crop biomass and these traits were observed. In barley and wheat, biomass at maturity was significantly $(\mathrm{P}<0.01$ or $\mathrm{P}<0.05)$ related to $\mathrm{t}_{\max }$ and DUR, while its relationship with $t_{\text {inf }}$ was positive, but not statistically significant $(\mathrm{P}>0.05)$. Crops sown in early sowing dates had higher duration of these phases (Table 2), resulting in increase of crop biomass at maturity. By delaying the sowing from SD1 to SD4, duration of these phases was reduced almost linearly, leading to a significant decrease of crop biomass both 

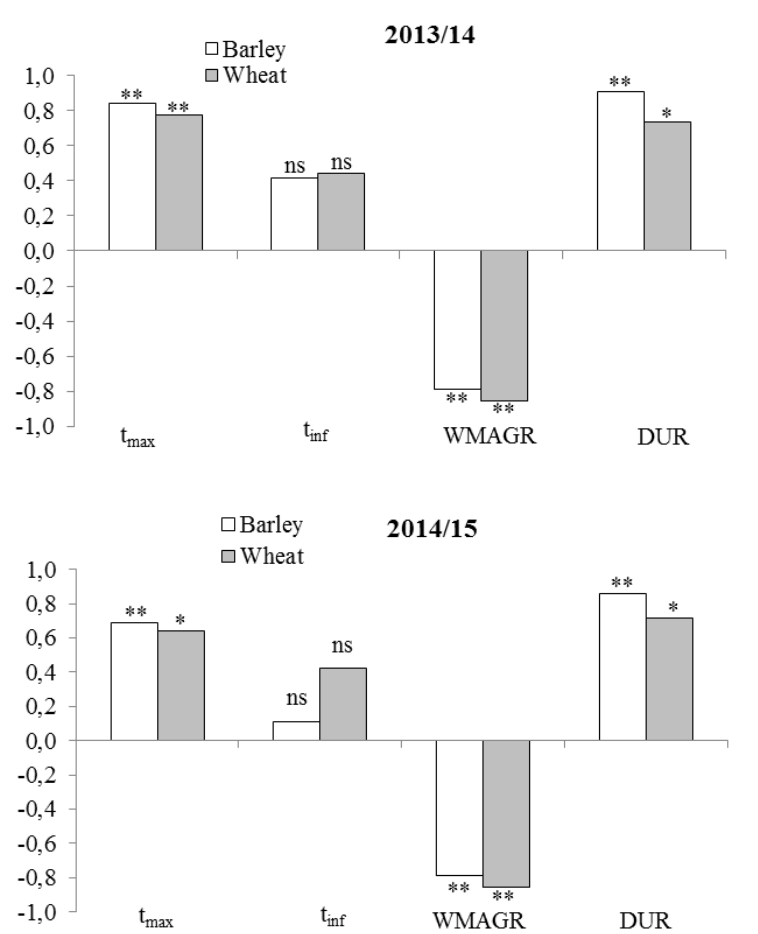

Figure 4. Correlation between crop biomass at maturity and biological variables of logistic curve (Mxa $t_{\max }$ - the thermal time required to reach $0.95 \mathrm{y}$ asym, $\mathrm{t}_{\mathrm{inf}}$ - thermal time needed to reach maximum growth rate, WMAGR - weighted mean absolute growth rate, $\mathrm{Cm}$ - The maximum crop growth rate, DUR - duration of exponential growth) in wheat and barley in two growing seasons averaged across four sowing dates

in wheat and barley. Decrease in the duration of crop cycle under late sowing date is related to the differences in duration of the pre-anthesis and post anthesis period (Prado et al., 2013). Crops sown in early sowing dates (SD1 and SD2) receive higher level of incident radiation and accumulate more temperature over the duration of their growth influencing leaf appearance, canopy closure and interception of photosynthetic active radiation (Martini et al., 2009). Generally, higher level of intercepted photosynthetic active radiation is positively related to aboveground biomass both in wheat and barley (Prado et al., 2017). Next to the duration of crop cycle, period of exponential crop growth is one of the most important phases in biomass accumulation, since the highest part of crop biomass is accumulated during this period. Early sowing of wheat and barley prolong the duration of DUR period, enabling higher biomass accumulation.

On the other hand, relationship between $\mathrm{BM}$ and WMAGR was negative in both seasons $(\mathrm{P}<0.01)$. The values of WMAGR significantly increased by delaying the sowing date, which negatively affected crop biomass production. Yusoff (2012) reported the presence of a compensatory change in WMAGR and DUR in different crops. Therefore, increased crop biomass in earlier sowing was the result of DUR increase rather than the differences in their growth rates.

\section{Conclusion}

In conclusion, crop biomass at maturity was positively related to grain yield both in wheat and barley. The highest grain yield and crop biomass at maturity were obtained with early sowing (SD1 and SD2). Moreover, barley and wheat had similar strategies for biomass determination. Crop biomass at maturity was positively associated with the duration of growing phases, while relationship with weighted mean absolute growth rate was negative. Early sowing enables prolongation in duration of different phases of crop biomass accumulation, leading to significant biomass and grain yield increase.

\section{References}

Agegnehu, G., van Beek, C., \& Bird, M.I. (2014). Influence of integrated soil fertility management in wheat and tef productivity and soil chemical properties in the highland tropical environment. Journal of soil science and plant nutrition, 14(3), 532-545.

Archontoulis, S.V., \& Miguez, F.E. (2015). Nonlinear regression models and applications in agricultural research. Agronomy Journal, 107(2), 786-798

Aynehband A, Valipoor M, Fateh E. 2011. Stem reserve accumulation and mobilization in wheat (Triticum aestivum L.) as affected by sowing date and N-P-K levels under Mediterranean conditions. Turkish Journal of Agriculture and Forestry. 35: 319-331.

Brdar, M., Kraljević-Balalić, M., \& Kobiljski, B. (2008). The parameters of grain filling and yield components in common wheat (Triticum aestivum L.) and durum wheat (Triticum turgidum L. var. durum). Central European Journal of Biology, 3(1), 75-82.

Cossani, C.M., Slafer, G.A., \& Savin, R. (2011). Do barley and wheat (bread and durum) differ in grain weight stability through seasons and water-nitrogen treatments in a Mediterranean location? Field Crops Research, 121, 240-247.

Danalatos, N.G., Archontoulis, S.V., \& Tsiboukas, K. (2009). Comparative analysis of sorghum versus corn growing under optimum and under water/nitrogen limited conditions in central Greece. In: From research to industry and markets: Proceedings of the 17th European Biomass Conference, ETA-Renewable Energies, Florence, Italy. pp 538-544. 29 June-3 July 2009. Hamburg, Germany.

Darroch, B.A., \& Baker, R.J. (1990). Grain filling in three spring wheat genotypes: statistical analysis. Crop Sciences, 30, 525-529.

de San Celedonio, R.P., Abeledo, L.G, \& Miralles, D.J. (2014). Identifying the critical period for waterlogging on yield and its components in wheat and barley. Plant and Soil, 378, 265-277.

Dimitrijević, M., Knežević, D., Petrović, S., Zečević, V., Bošković, J., Belić, M., Pejić, B., \& Banjac, B. (2011). Stability of yield components in wheat (Triticum aestivum L.). Genetika, 43(1), 29-39.

Dodig, D., Savić, J., Kandić, V., Zorić, M., Vucelić Radović, B., Popović, A., \& Quarrie, S. (2016). Responses of wheat plants under post-anthesis stress induced by defoliation: I. contribution of agro-physiological traits to grain yield. Experimental Agriculture, $52,203-223$.

Dodig, D., Rančić, D., Vucelić Radović, B., Zorić, M., Savić, J. Kandić, V., Pecinar, I., Stanojević, S., Šešlija, A., Vassilev, D., \& Pekić-Quarrie, S. (2017): Response of wheat plants under postanthesis stress induced by defoliation: II. Contribution of peduncle morpho-anatomical traits and carbon reserves to grain yield. The Journal of Agricultural Science, 155:475-493.

Ehdaie, B., Alloush, G., \& Waine, J. (2008). Genotypic variation in linear rate of grain growth and contribution of stem reserves to grain yield in wheat. Field Crops Research, 106, 34-43.

Ferrise, R., Triossi, A., Stratonovitch, P., Bindi, M., \& Martre, P. (2010). Sowing date and nitrogen fertilisation effects on dry matter and nitrogen dynamics for durum wheat: an experimental and simulation study. Field Crops Research, 117, 245-257. 
Gan, Y., Stobbe, E.H., \& Njue, C. (1996). Evaluation of selected nonlinear regression models in quantifying seedling emergence rate of spring wheat. Crop Sciences, 36, 165-168

García, G.A., Hasan, A.K., Puhl, L.E., Reynolds, M.P., Calderini, D.F., \& Miralles, D.J. (2013). Grain yield potential strategies in an elite wheat double-haploid population grown in contrasting environments. Crop Sciences, 53, 2577-2587.

Jia, B., He, H.B., Ma, F.Y., Diao, M., Jiang, G.Y., Zheng, Z., Cui, J., \& Fan, H. (2014). Modeling aboveground biomass accumulation of cotton. The Journal of Animal and Plant Sciences, 24(1), 280-289.

Karadavut, U. (2009). Non-linear models for growth curves of triticale plants under irrigation conditions. Turkish Journal of Agriculture and Forestry, 14(2), 105-110.

Kiss, T., Balla, K., Bányai, J., Veisz, O., \& Karsai, I. (2014). Effect of different sowing times on the plant developmental parameters of wheat (Triticum aestivum L.). Cereal Research Communications, 42(2), 239-251.

Koutroubas, S.D., Fotiadis, S., \& Damalas, C.A. (2012). Biomass and nitrogen accumulation and translocation in spelt (Triticum spelta) grown in a Mediterranean area. Field Crops Research, 127, 1-8.

Madani, A., Rad, A.S., Pazoki, A., Nourmohammadi, G., \& Zarghami, R. (2010). Wheat (Triticum aestivum L.) grain filling and dry matter partitioning responses to source: sink modifications under postanthesis water and nitrogen deficiency. Acta Scientiarum Agronomy, 32(1), 145-151.

Martini, M.Y., McKenzie, B.A., Moot, D.J., Hill, G.D., \& de Ruiter, J.M. (2009). Dry matter accumulation of oats sown at five different sowing dates. Agronomy New Zealand, 39, 71-80.

Meade, K.A., Cooper, M., \& Beavis, W.D. (2013). Modeling biomass accumulation in maize kernels. Field Crops Research, 151, 92-100.

Melchiori, R., \& Caviglia, O. (2008). Maize kernel growth and kernel water relations as affected by nitrogen supply. Field Crops Research, 108, 198-205.

Mirosavljević, M., Pržulj, N., Momčilović, V., Hristov, N., \& Maksimović, I. (2015). Dry matter accumulation and remobilization in winter barley as affected by genotype and sowing date. Genetika, 47, 751-763.

Mirosavljević, M., Momčilović, V., Mikić, S., Trkulja, D., Denčić, S., Jocković, B., Aćin, V., \& Pržulj, N. (2017). Variation in grain filling of winter cereals in Pannonian Plain. In: 4th Conference of Cereal Biotechnology and Breeding jointly organized by EUCARPIA Cereal Section: Book of Abstracts. 6 - 9 November 2017. Pp in press Budapest, Hungary

Munakamwe, Z., McKenzie, B.A., \& Hill, G.D. (2014). The effect of genotype and agronomic factors on crop growth and yield in field peas (Pisum sativum L.) as influenced by radiation interception and utilisation. Australian Journal of Crop Science, 8(5), 680-688.

Pagelow, Jr., E.J., Taylor, B.B., Horrocks, R.D., Buxton, D.R., Marx, D.M., \& Wanjura, D.F. (1977). The Gompertz function as a model for cotton hypocotyl elongation. Agronomy Journal, 69: 875-878
Peek, M.S., Russek-Cohen, E., Wait, D.A., \& Forseth, I.N. (2002) Physiological response curve analysis using nonlinear mixed models. Oecologia, 132, 175-180.

Prado, S., Gallardo, J.M., Serrago, R.A., Kruk, B.C., \& Miralles, D.J. (2013). Comparative behavior of wheat and barley associated with field release and grain weight determination. Field Crops Research, 144, 28-33.

Prado, S.A., Gallardo, J.M., Kruk, B.C., \& Miralles, D.J. (2017). Strategies for yield determination of bread wheat and two-row barley growing under different environments: A comparative study. Field Crops Research, 203, 94-105.

Pržulj, N., \& Momčilović, V. (2011a). Characterization of vegetative and grain filling periods of winter wheat by stepwise regression procedure: I. Vegetative period. Genetika, 43(2), 349-359.

Pržulj, N., \& Momčilović, V. (2011b). Characterization of vegetative and grain filling periods of winter wheat by stepwise regression procedure. II. Grain filling period. Genetika, 43(3), 549-558

Pržulj, N., Mirosavljević, M., Čanak, P., Zorić, M., \& Boćanski, J. (2015). Evaluation of spring barley performance by biplot analysis. Cereal Research Communications, 43(4), 692-703.

Savić, J., Kandić, V., Rančić, Pećinar, I., Šešlija, A., Ivanović, D., Bratković, K., \& Dodig, D. (2017): Association of agronomical, morphological and anatomical traits with compensatory effect of stem reserve mobilization in common wheat genotypes under drought stress. Italian Journal of Agrometeorology, 22(3), 5-12.

Thornley, J.H.M., \& France, J. (2007). Mathematical Models in Agriculture: quantitative methods for the plant, animal and ecological sciences, pp 906. CAB International (2nd Edn.). Wallingford UK.

Verhulst, P.F. (1838). A note on population growth. Correspondance Math Phys, 10, 113-121.

Villegas, D., Aparicio, N., Blanco, R., \& Royo, C. (2001). Biomass accumulation and main stem elongation of durum wheat grown under Mediterranean conditions. Annals of Botany, 88, 617-627.

White, J.W., Kimball, B.A., Wall, G.W., Ottman, M.J., \& Hunt, L.A. (2011). Responses of time of anthesis and maturity to sowing dates and infrared warming in spring wheat. Field Crops Research, 124, 213 -222 .

Yin, X., Goudriaa, J.A.N., Lantinga, E.A., Vos, J.A.N., \& Spiertz, H.J. (2003). A flexible sigmoid function of determinate growth. Annals of Botany, 91, 361-371.

Yusoff, M.M. (2012). Physiological and environmental constraints to winter forage crops production. Doctoral dissertation, pp 168. Lincoln University, New Zealand.

Zhou, B., Sanz-Sáez, A., Elazab, A., Shen, T., Sánchez-Bragado, R., Bort, J., Serret, M.D., \& Araus, J.L. (2014). Physiological traits contributed to the recent increase in yield potential of winter wheat from Henan Province. Journal of Integrative Plant Biology, 56, 492-504.

\section{Akumulacija suve materije ozime pšenice $\mathrm{i}$ ječma u različitim rokovima setve}

\section{Milan Mirosavljević · Vojislava Momčilović · Novo Pržulj · Ivana Maksimović · Marina Putnik Delić}

Sažetak: Akumulacija suve materije je jedan od najboljih pokazatelja reakcije useva na uticaj genotipa i faktora sredine. Međutim, nedostaju uporedni podaci o rastu pšenice i ječma u uslovima Panonske nizije. Cilj ovog istraživanja je bilo ispitivanje $i$ poređenje akumulacije suve materije pšenice i ječma i utvrđivanja značaja parametara logističke krive u formiranju ukupne biomase. Ogled sa dve sorte dvoredog ozimog ječma i dve sorte ozime pšenice je sejan dve sezone u četiri roka setve. Rezultati ovog ispitivanja ukazuju da je prinos zrna i suve materije bio pod značajnim uticajem roka setve i genotipa u obe sezone. Setva u prvom i drugom roku dala je najveći prinos zrna i biomase. Utvrđena je pozitvna veza između biomase useva i prinosa zrna kod obe vrste. Pšenica i ječam su imali slične tendencije u nakupljanju suve materije. Biomasa u zrelosti je bila u pozitivnoj vezi sa dužinom vegetacionog perioda, a u negativnoj vezi sa procenjenom srednjom apsolutnom brzinom rasta. Rana setva omogućava produženje trajanja različitih faza akumulacije suve materije, dovodeći do značajnog povećanja prinosa i suve materije kod ječma i pšenice.

Ključne reči: biomasa, ječam, prinos zrna, pšenica, setva, suva materija 